\title{
A workplace farmstand pilot programme in Omaha, Nebraska, USA
}

\author{
Farryl MW Bertmann ${ }^{1}$, Hollyanne E Fricke ${ }^{2, *}$, Leah R Carpenter ${ }^{2}$, Daniel J Schober ${ }^{2}$, \\ Teresa M Smith², Courtney A Pinard ${ }^{2}$ and Amy L Yaroch ${ }^{2}$ \\ 'Public Health Nutrition and Dietetics Research Consultant, South Hero, VT, USA: ${ }^{2}$ Gretchen Swanson Center for \\ Nutrition, 8401 West Dodge Road - Suite 100, Omaha, NE 68114, USA
}

Submitted 23 February 2015: Final revision received 7 April 2015: Accepted 20 April 2015: First published online 28 May 2015

\begin{abstract}
Objective: To explore the feasibility of a workplace farmstand programme through the utilization of an online ordering system to build awareness for local food systems, encourage community participation, and increase local fruit and vegetable availability.

Design: A 4-week pilot to explore feasibility of workplace farmstand programmes through a variety of outcome measures, including survey, mode of sale, weekly sales totals and intercept interviews.

Setting: A large private company in Sarpy County, Omaha, Nebraska, USA.

Subjects: Employees of the company hosting the farmstand programme.

Results: Pre-programme, a majority of employees indicated that quality (95.4\%), variety $(94.6 \%)$ and cost of fruits and vegetables (86.4\%) were driving factors in their fruit and vegetable selection when shopping. The availability of locally or regionally produced fruits and vegetables was highly important (78.1\%). Participants varied in their definition of local food, with nearly half (49.2\%) reporting within $80.5 \mathrm{~km}$ (50 miles), followed by $160.9 \mathrm{~km}$ (100 miles; $29.5 \%)$ and $321.9 \mathrm{~km}$ (200 miles; $12 \cdot 1 \%$ ). Weekly farmstand purchases (both walk-ups and online orders) ranged from twenty-eight to thirty-nine employees, with weekly sales ranging from \$US 257.95 to 436.90 for the producer. The mode of purchase changed throughout the pilot, with higher use of online ordering in the beginning and higher use of walk-up purchasing at the end.

Conclusions: The workplace farmstand pilot study revealed initial interest by both employees and a producer in this type of programme, helped to establish a sustained producer-employer relationship and led to additional opportunities for both the producer and employer.
\end{abstract}

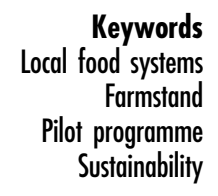

The food system has a major impact on the economy, the environment and ultimately the health of the nation ${ }^{(1-6)}$. In the USA, the current food system may be contributing to the obesity epidemic through a variety of avenues, including the wide availability of energy-dense, nutrientpoor foods at relatively low prices ${ }^{(4,5,7)}$. Exploring ways to shift the food system so that it promotes the purchase and consumption of more healthful foods (e.g. fruits and vegetables) while limiting the broad availability of less healthful foods is an important strategy in controlling the rising rates of obesity ${ }^{(3-5)}$. In order to do so, leading public health experts posit that policy and environmental approaches can have a far-reaching impact by enabling consumer decisions for choosing more healthful foods ${ }^{(7,8)}$. Environmental approaches in particular, because of their opportunity to create population-wide rather than individual-level improvement, are more likely to contribute to the establishment of a sustainable food system in a community.

A sustainable food system encourages local production and distribution infrastructures and makes nutritious foods available, accessible and affordable to everyone now and in the future ${ }^{(2,9,10)}$. Producers, consumers and other key stakeholders within the local food system, such as distributors, have the ability to impact accessibility and consumption of more healthful foods ${ }^{(11)}$. As awareness of and interest in local food systems has grown, a variety of institutions have begun to create and adopt farmstand programmes, whereby local producers sell their produce and other value-added products in a variety of settings, including schools, hospitals and workplaces ${ }^{(12,13)}$. Specifically, workplaces have implemented farmstand 
programmes as part of a growing interest in supporting local economies and as part of larger wellness initiatives $^{(12,14)}$. Workplace farmstand programmes provide a unique opportunity to both support local food systems and promote more healthful eating among employees. Because farmstand programmes traditionally arrange for produce to be delivered directly to the workplace, these programmes can decrease potential barriers to purchasing local foods, such as access, affordability and convenience ${ }^{(7)}$. A major benefit for producers is that farmstand programmes enable them to retain a greater share of their sales when they sell locally ${ }^{(15)}$.

Workplace farmstand programmes can take many different forms. For example, participants may receive a box of produce based on a producer's inventory during a given growing cycle; this is a comparable structure to many community-supported agriculture programmes, which are similarly gaining widespread popularity ${ }^{(16)}$. Other options include a farmer's market-style display, which allows employees to visit the booth at their workplace during designated times. Alternatively, some farmstand programmes allow employees to place online orders each week, giving individuals more control over what produce they order and receive.

Prior to the current pilot, we conducted a state-wide needs assessment around local food systems, which demonstrated the need for future work in: (i) increasing consumer education about local food systems and nutrition; and (ii) increasing producer capacity through direct-to-consumer outlets ${ }^{(17)}$. As a result of this assessment, we developed and implemented a 4-week workplace farmstand pilot programme at a large, international, private data processing and preparation company with an annual revenue estimated at between \$US 100 and 500 million. This organization employs approximately 25000 to 50000 individuals nationally, with a workforce of approximately 3000 at their Sarpy County (Omaha area) headquarters, Nebraska, USA. Since this was a pilot, we engaged a single local producer to supply the produce for this project. The producer's farm is located in Pottawattamie County, Iowa, approximately $85 \mathrm{~km}$ (53 miles) from the company; the farm grows 0.61 ha ( 1.5 acres) of produce and 0.61 ha ( 1.5 acres) of small fruit, utilizing sustainable practices such as integrated pest management.

During the project, employees placed weekly orders for produce and value-added goods through an online ordering system and subsequently paid for and picked up their orders at the workplace. The online ordering method reduces the risk for the producer due to orders being placed in advance of the distribution day and ensuring those items are sold. We hypothesized that employees participating in the programme would: (i) become more aware of local food systems; (ii) have improved access to affordable produce; and (iii) have increased fruit and vegetable $(\mathrm{FV})$ intake.

\section{Methods}

\section{Pilot design}

Two months prior to the start of the pilot, materials describing the programme and an opportunity to 'meet the farmer' were provided during an annual health fair for company employees. Two weeks prior to the start of the programme, all company employees received an introductory message re-announcing the programme via the company's internal messaging hub. During the 4-week programme period, employees placed weekly orders for produce through an online local food ordering system and subsequently picked up their orders at the workplace, during a designated time window. Reminder messages were sent, including information about the farm, instructions for online ordering, pick-up information and each week's available produce. In addition to fulfilling online orders, additional produce was made available and walk-up (or à la carte) purchases were also accepted. Mode of purchase was tracked over the four weeks of the programme and reported as 'pre-order' or 'walk-up'. Pre-order depicts participants who used the online ordering system to place their weekly produce order. Total sales for both modes of purchase were collected on a weekly basis.

\section{Assessment}

An online survey was sent to employees via SurveyMonkey.com prior to programme launch to assess potential barriers and facilitators towards the farmstand programme ( $n$ 133). Upon completion of the survey, participants could print a coupon for $\$$ US 2 off their produce order, for use at any time throughout the programme. The survey included twenty-eight items, mainly consisting of attitudes and perceptions (e.g. attitudes toward local foods; perceived access to affordable healthy foods; local food purchasing habits), as well as a two-item FV screener to assess FV intake, selected from the National Cancer Institute's Food Attitudes and Behavior Survey ${ }^{(18)}$. As a post-test, we also administered the online survey after the programme was completed ( $n$ 21), but due to the small sample size, results for the post-test are not shown.

\section{Analysis}

To strengthen interpretation of Likert-scaled questions in the pre-programme survey, responses of 'strongly disagree' and 'somewhat disagree' were collapsed into 'disagree' while responses of 'somewhat agree' and 'strongly agree' were collapsed into 'agree'.

\section{On-site intercept interviews}

Each week, two members of the research team (H.E.F., L.R.C.) conducted short, semi-structured intercept interviews, both with employees and the producer. Employees were asked to describe their experience participating in the farmstand programme, what improvements could be 
made to the programme and whether they would participate in a similar programme in the future. Similarly, the producer was asked about his experience in the programme, what improvements could be made in the future and the likelihood of participating in similar programmes in the future. Interviews were audio recorded and researchers noted emergent themes.

\section{Results}

\section{Survey}

Demographics for the 133 employees who completed the pre-programme survey are reported in Table 1. Participants were mainly female and had a range of income levels.

The majority of employees reported consuming 1-2 cups of fruits (24\%) and vegetables (29\%) daily, followed by $2-3$ cups daily (fruits, $18.3 \%$; vegetables, $19 \cdot 1 \%$ ). Most of the employees $(76.6 \%)$ reported that they felt confident in their ability to eat FV every day. Employees were asked to report how many servings of FV they thought a person should eat each day for good health; responses averaged 4.7 (SD 1.6) servings.

Employees were given a list of potential reasons for why they may not be eating FV as much as they would like. The majority of employees indicated agreement that FV often spoil before they get the chance to eat them $(65 \cdot 1 \%)$. More than one-third of employees indicated that FV cost too much (33.4\%) and approximately one-quarter of employees indicated that $\mathrm{FV}$ take too much time to prepare $(26.5 \%)$.

Employees were asked to indicate reasons for selecting where the primary food shopper(s) in the household buys groceries. The majority of employees (95.4\%) indicated that the quality and freshness of FV is an important reason, followed by stores having a wide variety of FV (94.6\%) and affordability of FV (86.4\%). The availability of locally or regionally produced $\mathrm{FV}$ was also reported as highly important to employees (78.1\%). When asked about what they would consider local foods in geographic terms, employees most often indicated $80.5 \mathrm{~km}$ (50 miles) to be the maximum distance they would consider local (49.2\%),

Table 1 Demographics of employees completing the survey (n 133)

\begin{tabular}{lrr}
\hline & $\%$ & $n$ \\
\hline Sex & & \\
$\quad$ Female & $70 \cdot 3$ & 90 \\
Male & $29 \cdot 7$ & 38 \\
Income (\$US) & & \\
Under 11999 & $0 \cdot 0$ & 0 \\
12 000-24 999 & $1 \cdot 6$ & 2 \\
25 000-34 999 & $5 \cdot 7$ & 7 \\
35 000-49 999 & $15 \cdot 6$ & 30 \\
50 000-64 999 & $24 \cdot 6$ & 64 \\
Over 65 000 & 52.5 & \\
\hline
\end{tabular}

followed by $160.9 \mathrm{~km}$ (100 miles; $29 \cdot 5 \%$ ), $321.9 \mathrm{~km}$ (200 miles; 12.1\%) and 'not sure' (9.2\%).

Weekly farmstand participants (both walk-ups and pre-orders) ranged from twenty-eight to thirty-nine people, while weekly sales for the producer ranged from \$US 257.95 to 436.90 (Table 2). The mode of purchase shifted throughout the programme, from higher amounts of preorders in the beginning to greater use of walk-up purchases by the end of the programme. Employees mentioned that they were not aware of the programme, and particularly the availability of the à la carte option. Some employees reported preferring the walk-up method, citing that the online ordering system was difficult to use.

\section{Onsite intercept interviews}

Five intercept interviews were conducted. Responses were mostly positive, with participants indicating that the ordering system was easy to use, that the pick-up times and location were convenient and that they planned to continue utilizing this programme and similar programmes in the future. Employees also provided constructive feedback, including suggestions for produce in future weeks, how to make the ordering and pick-up instructions clearer and comments on the awareness of the programme. Selected participant quotes are displayed below:

'It was really great, easy to order online and fun.' (Employee)

'It was a good experience; the process of pre-ordering went very well.' (Producer)

'I just found out about it, but will use [the online ordering system] next week'. (Employee)

\section{Discussion}

To our knowledge, there are few published studies on farmstand programmes for worksites. Although we have limited post-programme survey responses, the current study still provides some important preliminary baseline information on attitudes and FV intake at a large workplace in Sarpy County (Omaha), Nebraska, USA. For instance, most of the employees who completed the preprogramme survey reported feeling confident in their ability to eat FV every day. In addition, the majority of

Table 2 Total sales for producer and number of participants, by week

\begin{tabular}{lccc}
\hline & Total sales (\$US) & Pre-orders & Walk-ups \\
\hline Week 1 & 318.32 & 28 & 2 \\
Week 2 & 257.95 & 17 & 11 \\
Week 3 & 419.32 & 19 & 25 \\
Week 4 & 436.90 & 16 & 23 \\
\hline
\end{tabular}


employees reported FV intake that fell short of the 2010 Dietary Guidelines for Americans (3.5-6.5 cups FV daily, depending on sex, age and activity level) ${ }^{(19)}$. Survey findings are consistent with lower FV intake in the general population and reaffirm the need for innovative strategies, both within and outside the workplace, to help promote greater FV intake ${ }^{(20,21)}$.

For employees, workplace farmstand programmes have the potential to increase awareness of local food systems and exposure to locally harvested produce, which may have enhanced taste and quality ${ }^{(5,22)}$. By providing access to FV in the workplace, self-efficacy, which has been identified as a predictor of FV intake, could be improved $^{(7,23)}$. Producers may also benefit from social and economic capital gained when participating in farmstand programmes $^{(5)}$. Online purchasing options may provide producers with more security in terms of sales totals to expect and consequently may help producers in better estimating how much product to harvest and transport, thereby reducing waste.

Future workplace farmstand programmes should consider providing both the online and à la carte purchasing option, as the present study found that the à la carte option increased overall sales and participation in the programme. However, producers should be strategic when offering this option, as it does not help estimate harvest amounts and could result in waste. Although the producer in our pilot offered both online ordering and à la carte purchasing, he strategically chose to bring items with a longer shelf-life as à la carte options, which could be sold at the farmers' market later in the week if they did not sell on-site. On average, approximately twenty items were available in the online inventory each week, while approximately ten items were available à la carte.

Although the present study did not include a formal impact evaluation, follow-up communication with both the producer and employer revealed some initial successes. The producer and employer continued the farmstand programme for a second year (without our involvement); new items were added to the inventory based on participant feedback both during and after our pilot, and employees continued to rate the programme positively, as anecdotally reported by the employer. Further, conversations with the employer revealed that it planned to invite the producer back for a third year and may expand the programme to include multiple producers, as well as work towards launching other workplace initiatives supporting local food systems. The producer's involvement in the programme has led to opportunities to supply produce for other workplace farmstand programmes.

\section{Programme limitations}

One major limitation to the current study is that it was conducted at a single site with a single producer. Second, we did not have full access to contact employees and relied on the company's internal messaging to post programme messages; direct email contact may have had a wider reach and in turn increased participation. Third, the pre-programme survey contains the inherent bias of self-assessment. Finally, only twenty-one employees completed the post-programme survey, which did not allow for any pre-post analyses. Although the study design did not allow for longer-term impact measurement, the current pilot programme remains one of the first studies reporting results and assessment from a workplace farmstand programme and has led to the establishment of a sustained relationship between the producer and the company, and potential to continue to raise awareness and consumption of FV.

\section{Conclusion}

The current pilot workplace farmstand programme, although small, revealed that interest exists in this approach. The fact that this programme was implemented in a conservative Midwestern state that does not tend to be progressive on local food systems issues and showed initial acceptability, success and sustainability have positive implications for implementation in other communities. The results of the study can inform researchers and practitioners on how to set up and assess feasibility of a farmstand programme. While it was not measured in the current study, increased exposure to a local producer could ultimately increase consumers' awareness of and participation in local food system avenues (e.g. added farmers' market visits, participation in community-supported agriculture, etc.). Although workplace farmstands alone cannot create sustainable impact, they represent one important way that employers, consumers and producers alike can collaboratively contribute to the establishment of a sustainable local food system.

\section{Acknowledgements}

Acknowledgements: The authors would like to thank Judy Grace and Andrea Constanzo, representatives of the organization with whom this pilot study was conducted, for their assistance with organizing and implementing the programme. Additionally, the authors would like to thank Mike Von Weihe, the local producer for this pilot programme. Financial support: This work was supported by a grant from the Howard G. Buffett Foundation. The funder had no role in the design, analysis or writing of this article. Conflict of interest: None. Authorship: F.M.W.B. and H.E.F. led the writing of the manuscript. L.R.C., D.J.S., C.A.P. and A.L.Y. contributed to the conceptualization of the project. H.E.F. and L.R.C. were responsible for programme implementation and data collection. T.M.S. conducted the data analysis. Ethics of buman subject participation: This study was approved by the University of Nebraska Medical Center Institutional Review Board. 


\section{References}

1. Neshiem MC, Oria M, Yih PT et al. (2015) A Framework for Assessing Effects of the Food System. Washington, DC: Institute of Medicine, National Research Council; available at http://www.nap.edu/catalog/18846/a-framework-forassessing-effects-of-the-food-system

2. American Public Health Association (2007) Toward a Healthy Sustainable Food System. http://www.apha.org/ policies-and-advocacy/public-health-policy-statements/policydatabase/2014/07/29/12/34/toward-a-healthy-sustainable-foodsystem (accessed February 2015).

3. Finney Rutten L, Yaroch AL, Patrick H et al. (2012) Obesity prevention and national food security: a food systems approach. Int Sch Res Not $\mathbf{2 0 1 2}$, article ID 539764.

4. Story M, Hamm MW \& Wallinga D (2009) Food systems and public health: linkages to achieve healthier diets and healthier communities. J Hunger Environ Nutr 4, 219-224.

5. Pinard CA, Kim SA, Story M et al. (2013) The food and water system: impacts on obesity. J Law Med Ethics 41, 52-60.

6. Connelly S, Markey S \& Roseland M (2011) Bridging sustainability and the social economy: achieving community transformation through local food initiatives. Crit Soc Policy 31, 308-324.

7. Story M, Kaphingst KM, Robinson-O'Brien R et al. (2008) Creating healthy food and eating environments: policy and environmental approaches. Annu Rev Public Health 29, 253-272.

8. Frieden TR (2010) A framework for public health action: the health impact pyramid. Am J Public Health 100, 590-595.

9. Dixon J (1999) A cultural economy model for studying food systems. Agric Hum Values 16, 151-160.

10. Lockie S (2002) The invisible mouth: mobilizing the consumer in food production-consumption networks. Soc Rural 42, 278-294.

11. Neff R (editor) (2014) Introduction to the US Food System: Public Health, Environment, and Equity, 1st ed. San Francisco, CA: Jossey-Bass.

12. US Department of Agriculture (2012) Farm to Institution Initiatives. http://www.usda.gov/documents/6-Farmtoinstitution.pdf (accessed March 2014).

13. Beery M \& Markeley K (2007) Farm to Hospital: Supporting Local Agriculture and Improving Health Care. http://scholar. oxy.edu/cgi/viewcontent.cgi?article=1380\&context=uep_faculty (accessed March 2014).
14. George DR, Kraschnewski JL \& Rovniak LS (2011) Public health potential of farmers' markets on medical center campuses: a case study from Penn State Milton S. Hershey Medical Center. Am J Public Health 101, 2226-2232.

15. King R, Hand M, DiGiacomo G et al. (2010) Comparing the Structure, Size, and Performance of Local and Mainstream Food Supply Chains. Economic Research Report no. ERR-99. http://www.ers.usda.gov/publications/err-economic-researchreport/err99.aspx (accessed March 2014).

16. Brown C \& Miller S (2008) The impacts of local markets: a review of research on farmers markets and community supported agriculture (CSA). Am J Agric Econ 90, 1298-1302.

17. Schober DJ, Smith TM, Carpenter LR et al. (2013) Local Food Systems in Nebraska: An Examination of Perceptions, Participation, \& Ideas for Change. Omaha, NE: Gretchen Swanson Center for Nutrition.

18. Yaroch AL, Tooze J, Thompson FE et al. (2012) Evaluation of three short dietary instruments to assess fruit and vegetable intake: the National Cancer Institute's food attitudes and behaviors survey. J Acad Nutr Diet 112, $1570-1577$.

19. US Department of Agriculture \& US Department of Health and Human Services (2010) Dietary Guidelines for Americans, 2010, 7th ed. http://www.health.gov/dietary guidelines/dga2010/dietaryguidelines2010.pdf (accessed March 2014).

20. Kant AK, Graubard BI \& Mattes RD (2012) Association of food form with self-reported 24-h energy intake and meal patterns in US adults: NHANES 2003-2008. Am J Clin Nutr 96, 1369-1378.

21. US Department of Agriculture, Agricultural Research Service (2014) What We Eat in America, NHANES 2011-2012, individuals 2 years and over (excluding breast-fed children), day 1 dietary intake data, weighted. Food Patterns Equivalent Database (FPED) 2011-2012. http://www.ars.usda.gov/ SP2UserFiles/Place/80400530/pdf/FPED/tables_1-4_FPED_ 1112.pdf (accessed May 2015).

22. Pray L (2014) Sustainable Diets: Food for Healthy People and a Healthy Planet: Workshop Summary. http://books. nap.edu/openbook.php?record_id=18578 (accessed March 2014).

23. Shaikh AR, Yaroch AL, Nebeling L et al. (2008) Psychosocial predictors of fruit and vegetable consumption in adults a review of the literature. Am J Prev Med 34, 535-543. 